\title{
The relationship between petroleum price and real exchange rate: an example of
} Iraq

\section{Dindar Saeed Saeeda, Sadeq Taha Abdulazeez ${ }^{\text {**, }}$, Sarbast Kamal Rasheed ${ }^{b}$, Rogash Younis Masihac, Diyar Hashim Malod}

a Department of Mathematics, Van Yüzüncü Yıl Üniversitesi, Van, Turkey

b Department of Mathematics, College of Basic education, University of Duhok, Iraq

c Department of Statistics, Van Yüzüncü Yıl Üniversitesi, Van, Turkey

d Department of Mathematics, College of Sciences, University of Duhok, Iraq, Duhok

Emails: dindar.qrepti@gmail.comª, sadiq.taha@uod.ac*b, Sarbastduski67@yahoo.com , rogashbabiri@gmail.comc, Diyar.Malo@uod.ac ${ }^{d}$

\begin{abstract}
Petroleum is one of the world's most important economic products. It is widely accepted that petroleum is not only an energy product, but also a financial asset. Therefore, it is important to understand the dependence of petroleum prices on economic conditions and financial markets and how they can affect the world economy. The fluctuations in world petroleum prices affect the economies of petroleum importing countries through different channels. One of the most important of these influence channels is the exchange rate. Because changes in exchange rates cause different economic problems in fragile economies. Changes in petroleum prices affect the economic performance of any country through various channels. One of the channels of influence is exchange rates. Petroleum prices affect the transfer of income from petroleum exporting countries to petroleum importing countries through trade and thus determine the exchange rate. In this study, the Relationship between Petroleum Price and Real Exchange Rate in Iraq was examined by ADF unit root test, Johansen-Juselius cointegration test and Granger causality analysis. For the analysis, the Petroleum Price and Real Exchange Rate data of Iraq were taken from the official website of the World Bank and transferred to the Eviews 10 program and necessary analyzes were made. The results of the analysis were analyzed and interpreted in tables.
\end{abstract}

Keywords: Petroleum Price; Real Exchange Rate; Unit Root; Cointegration; Causality.

2010 MSC: 62B05, $81 S 05$

\section{Introduction}

In addition to demand conditions such as income, tastes and preferences, supply conditions also affect the price of a good. Energy especially oil is one of the most important raw materials in a modern economy. Petroleum products are used in the production of transportation and energy, as well as in the production of petroleum and chemical products. Therefore, oil price is one of the key prices in the international economy and is widely used as a reference value for other energy sources [18].

Energy imports have a significant share in total imports, as well as affecting the price of crude oil, many imported inputs and manufactured goods. A change in the crude oil input used in export production cannot be fully reflected in the export sales price by the producer in competitive markets. For this reason, the balance of payments of oil-importing countries deteriorates, so that imported goods become relatively more expensive, and

\footnotetext{
* Corresponding author

Email address: sadiq.taha@uod.ac (Sadeq Taha Abdulazeez)

doi: 10.31559/glm2021.11.1.3

Received: 21 Aug 2021 Revised: 29 Aug 2021 Accepted: 3 Sept 2021
} 
thus their real national income is adversely affected. The increase in oil prices can lead to the depreciation of the domestic currency by increasing the import bill and reserve requirement [14].

The increase in the oil price causes the total production to decrease due to the increase in the cost of production and the decreasing demand level is balanced by the counter monetary policies followed by the central banks. On the other hand, an increase in the price of oil leads to a transfer of income from an oil-importing country to an oil-exporting country. The rise in the oil price may cause the commodity prices in the oil-importing country to rise relatively more. The resulting inflationary situation will cause an appreciation in the real exchange rates of oil importing countries [3].

The author in [19] consider the direct negative effects of high oil prices on the oil-importing country's balance of payments, as well as the indirect positive effects that may arise from the spending of the revenues obtained by the oil-exporting countries on the goods or assets of the importing country. Thus, he states that the initial and final effects of the oil price increase on the exchange rate may differ. According to this view, factors such as the share of the oil importing country in world oil imports, the share of those originating from the oil importing country in the foreign assets of the oil exporting country, and the share of the oil importing country in the oil exporting country's imports, determine the short and long-term effects of oil prices on the exchange rate. lead to differences in period effects. According to [19], empirically, the initial effect of oil price increases causes the dollar to appreciate and the final effect causes its depreciation. Krugman in [20] similarly explained the effect of the increase in oil price on the currency of the country that is the importer of this product, with the relative dependence on imports, the relative elasticity of demand, and the relative shares that oil-exporting countries receive from their increased expenditure on foreign goods and assets.

Although the relationship between oil prices and exchange rates has been widely discussed in applied studies, the existing literature differs in terms of country examples, applied methods and obtained results. For example, Chaudhuri and Daniel in [8] concluded that there is a cointegration relationship between the real exchange rate of the US dollar against the currencies of sixteen industrialized countries and real oil prices. Based on the results of the cointegration and causality method, Amanoa and Norden [1,2] also stated that oil prices may be the main source of permanent real exchange rate shocks for the USA, Germany and Japan.

Effects on the nominal exchange rate arise if the price of tradable goods is no longer assumed to be fixed. In this case, inflation and nominal exchange rate dynamics are related via purchasing power parity (PPP). If the price of oil increases, we expect currencies of countries with large oil dependence in the tradable sector to depreciate due to higher inflation. The response of the real exchange rate then depends on how the nominal exchange rate changes, but relative to the impact of any changes in the price of tradable (and non-tradable) goods described above in [6].

Bodart, Candelon, and Carpantier in [7] include thirty-two oil exporters (Nigeria, Iran, Gabon, Saudi Arabia, Venezuela, Kuwait, Syria, Qatar, Algeria, Cameroon, Ecuador, UAE, Sudan, Bahrain, Papua New Guinea, and Colombia). examined the effect of structural features such as exchange rate regime, financial openness, trade openness, export diversification and type of core commodities exported on real exchange rate for three developing countries. In the study, in which panel data methods were used, results were obtained that more flexible exchange rate regimes, openness to international capital movements and foreign trade cause the real exchange rate to be low in commodity price elasticity. However, contrary to expectations, the degree of diversification in exports for sub-Saharan African countries and oil-exporting countries was found to increase the elasticity of commodity prices by the real exchange rate. In the study conducted by Ngoma, Ismail and Yusop in [21] covering the African countries Egypt, Ghana, Nigeria, South Africa and Tunisia, Engle and Granger [13] and Enders and Siklos [12] cointegration methods and symmetrical and asymmetrical based on them. error correction models are used. In the study, results supporting the linear cointegration relationship for Egypt, South Africa and Tunisia, and the asymmetric cointegration relationship for Ghana and Niger were obtained.

As we all know oil products have an influence on almost every aspect of modern life. As a result, energy economists will not be shocked to learn that crude oil, a source of energy, and its numerous derivatives have become one of the most important measures of global economic activity in recent decades [23].

As it can be understood from the studies summarized above, the examination of the relationship between oil prices and exchange rates was initially mainly in the case of oil-importing developed countries. This issue has gained importance especially after the significant increase in oil prices in the 1970s and the negative developments in the economies of developed countries. But later on, the relationship between oil prices and exchange rate has been extensively discussed in terms of oil exporting countries. The absence of studies on Iraq in the literature gives a privilege to the work to be done on this subject. The aim of this study is to examine the relationship between oil imports and real exchange rate in Iraq.

In the study, the introduction and the literature are given in the first part. After the materials and methods used in the study are given in the second part, the analyzes and results are given in detail in the third part. In the fourth chapter, the conclusion of the study is given.

\section{Material and Method}

In this study, the relationship between oil price and real exchange rate in Iraq for the period 1995-2019 was examined by ADF unit root test, Johansen-Juselius cointegration test and Granger causality analysis. The data of 
Iraq were analyzed in the Eviews 10 program, which was obtained from the official website of the World Bank [25]. The study differs from other studies in the literature in terms of the examined period and aims to contribute to the literature. The analyzes applied in the study are given under the headings below.

\subsection{Augmented Dickey and Fuller (ADF, 1981) Unit Root Test}

In econometric studies, the stationarity of the data is tested first. It is accepted that the data with a unit root are not stationary, and they are made stationary by taking their differences [5]. Stationarity in time series means that the variance does not change depending on time [15]. The classical DF model established as a first-order autoregressive model $(\mathrm{AR}(1))$ is expressed by the equation below.

$$
Y_{t}=p Y_{t-1}+\varepsilon_{t}, \quad t=1,2, \ldots, n
$$

Here the variable $Y_{t}$ is actually $\mathrm{p}$. If $\mathrm{AR}(\mathrm{p})$ follows a first-order autoregressive process, then a specification error has occurred here and the error terms are autocorrelated. Also t is a time trend; $\varepsilon_{t}$ is the error term, $Y_{t}$ is the series used and $p$ is the lag number of the dependent variables. The DF distribution acts on the assumption that the error term exhibits clean sequence characteristics, and the autocorrelation of the error terms distorts this assumption. Therefore, in this case, the DF distribution is not valid. In their study, Dickey and Fuller in [10] suggested adding the lagged values of the difference of the dependent variable to the right side of the three models used in the Dickey and Fuller unit root test to solve this autocorrelation problem. Models arranged in this way are indicated by the equations below.

$$
\begin{aligned}
& \text { Model A: } \Delta Y_{t-1}=\theta Y_{t-1}+\sum_{i=2}^{p} \gamma_{i} \Delta Y_{t-i+1}+\varepsilon_{t}, \quad Y_{0}=0 \\
& \text { Model B: } \Delta Y_{t-1}=\mu+\theta Y_{t-1}+\sum_{i=2}^{p} \gamma_{i} \Delta Y_{t-i+1}+\varepsilon_{t}, \quad Y_{0}=0 \\
& \text { Model C: } \Delta Y_{t-1}=\mu+\beta_{t}+\theta Y_{t-1}+\sum_{i=2}^{p} \gamma_{i} \Delta Y_{t-i+1}+\varepsilon_{t}, \quad Y_{0}=0
\end{aligned}
$$

Here $\Delta$ is the first difference operator; $\mathrm{t}$ is a time trend; $\varepsilon_{t}$ is the error term, $Y_{t}$ is the series used and $p$ is the lag number of the dependent variable determined by the Akaike Information Criteria to eliminate the sequential dependence of the error terms.

As in the DF unit root test, the hypotheses of the Augmented Dickey and Fuller [10] unit root test are as follows:

$$
\begin{gathered}
H_{0}: \theta=0 \\
H_{1}: \theta<0, \text { is in the form. }
\end{gathered}
$$

\subsection{Johansen - Juselius Cointegration Test}

Cointegration is obtaining a long-run relationship between two or more non-stationary variables. In other words, it shows the long-term movements of non-stationary variables [22]. Cointegration has been a commonly used method because it prevents spurious regression results. In the literature, there are many studies on the estimation of the cointegration vector. Co-integration is defined as a method that tests whether there is a long-run equilibrium relationship between variables and allows to predict the relationship directly [9]. The most commonly used methods are the Engle and Granger [13] two-stage cointegration test and the maximum likelihood cointegration test proposed in [16]. The equation used by Johansen and Juselius [17] in their work is as follows:

$$
\sum_{t=1}^{n} Z_{o t} Z_{1 t}^{!}=\Gamma \sum_{t=1}^{n} Z_{1 t} Z_{1 t}^{!}+\pi \sum_{t=1}^{n} Z_{k t} Z_{1 t}^{!}
$$

\subsection{Granger Causality Test}

The application in which the lag structure and direction of the relations between the variables are determined is called "Granger Causality Test". The purpose of this test; In models where there is more than one variable, it is possible to define it as determining the one-way or two-way (reciprocal) relationship between the variables [24].

In the Granger causality test, the direction of a relationship between two variables in the form of $\mathrm{X}$ and $\mathrm{Y}$ is investigated. In the model with two variables, the following formulas are applied while determining the effect relationship between the variables.

$$
\begin{aligned}
Y_{t} & =\sum_{i=1}^{p} \alpha_{i} Y_{t-1}+\sum_{i=1}^{p} \beta_{i} X_{t-1}+\varepsilon_{1 t}, \\
X_{t} & =\sum_{i=1}^{p} \alpha_{i} X_{t-1}+\sum_{i=1}^{p} \beta_{i} Y_{t-1}+\varepsilon_{2 t} .
\end{aligned}
$$

In here, $Y_{t}$ shows the dependent varibles. $X_{t}$ shows the independent varibles. $\alpha$ and $\beta$ shows the coefficients of independent variables. Also $\varepsilon$ shows the error terms and $t$ is a time trend.

\section{Analysis and Findings}

Examining the unit root test results for both oil price and real exchange rate variables, it is seen that both variables are stationary at the I(1) level. When looking at the LR, FPE, AIC and HQ criteria for the VAR model, it is 
seen that the lag length should be determined as 2 . In order to determine the optimal delay level, it was decided to take the delay level as 2 in the analysis, since the four delay criteria express 2 delays.

Table (1): Petroleum Price ADF Unit Root Test Results

\begin{tabular}{|c|c|c|c|c|c|c|}
\hline \multirow{3}{*}{$\begin{array}{l}\mathrm{I}(\mathbf{0}) \\
\begin{array}{l}\text { Test Critical } \\
\text { Value }\end{array}\end{array}$} & & $\mathrm{I}(1)$ & & & & \\
\hline & t-statistics & \multirow[b]{2}{*}{$\begin{array}{l}\text { p- Probability } \\
\text { Value }\end{array}$} & \multirow{2}{*}{\multicolumn{2}{|c|}{$\begin{array}{l}\text { Test Critical } \\
\text { Value }\end{array}$}} & t-statistics & \multirow{2}{*}{$\begin{array}{l}\text { p- } \\
\text { Probability } \\
\text { Value }\end{array}$} \\
\hline & $\begin{array}{c}\text { ADF Test Statistics } \\
\text { Value } 4.138958\end{array}$ & & & & $\begin{array}{l}\text { ADF Test Statistics Value } \\
-5.522849\end{array}$ & \\
\hline $5 \%$ & -2.991878 & 0.091 & $5 \%$ & & -3.004861 & 0.001 \\
\hline
\end{tabular}

When Table 1 is examined, it is observed that the data of Petroleum Price are not stationary at the level, they become stationary by taking the first-degree differences.

Table (2): Real Exchange Rate ADF Unit Root Test Results

\begin{tabular}{|c|c|c|c|c|c|c|c|}
\hline $\mathrm{I}(0)$ & & & $\mathrm{I}(1)$ & & & & \\
\hline \multirow{2}{*}{$\begin{array}{l}\text { Test Critical } \\
\text { Value }\end{array}$} & \multicolumn{2}{|c|}{ t-statistics } & \multirow[b]{2}{*}{$\begin{array}{l}\text { p- Probability } \\
\text { Value }\end{array}$} & \multirow{2}{*}{$\begin{array}{l}\text { Test } \\
\text { Value }\end{array}$} & \multirow[t]{2}{*}{ Critical } & t-statistics & \multirow[b]{2}{*}{$\begin{array}{l}\text { p- } \\
\text { Probability } \\
\text { Value }\end{array}$} \\
\hline & $\begin{array}{l}\text { ADF } \\
\text { Value }\end{array}$ & 4.138958 & & & & $\begin{array}{l}\text { ADF Test Statistics Value } \\
-5.522849\end{array}$ & \\
\hline $5 \%$ & -2.635 & 542 & 0.134 & $5 \%$ & & -2.642242 & 0.001 \\
\hline
\end{tabular}

When Table 2 is examined, it is observed that the data of the Real Exchange Rate are not stationary at the level, they become stationary by taking the first-degree differences. Table 3 below gives us the appropriate lag criterion.

Table (3): VAR Appropriate Lag Criteria

\begin{tabular}{lllllll}
\hline Lag & LogL & LR & FPE & AIC & SC & HQ \\
\hline 0 & -82.80206 & NA & 7.641921 & 7.709278 & 7.808463 & 7.732643 \\
1 & -39.44337 & 74.89228 & 0.214141 & 4.131215 & 4.428772 & 4.201311 \\
2 & -30.06014 & $14.50135^{*}$ & $0.132952^{*}$ & $3.641831^{*}$ & $4.137759^{*}$ & $3.758657^{*}$ \\
\hline
\end{tabular}

In here, Likelihood Ratio (LR), Final Prediction Error (FPE), Akaike (AIC), Schwarz (SC) and Hannan Quinn (HQ).

When Table 3 is examined, it is seen that the appropriate lag is 2. * marks give us the appropriate lag.

After the stationarity levels of the two variables in the analyzes were determined and the appropriate lag criterion was selected, the stage of examining the cointegration relationship was started. In the empirical application phase of the study, the Johansen - Juselius cointegration test was used to examine the long-term relationship between oil price and real exchange rate variables for the period covering 1995-2019 for the Iraqi economy. In Tables 4 and 5, the cointegration test results are given in detail.

Table (4): Johansen - Juselius cointegration - Trace test

\begin{tabular}{lllll}
\hline Hypothesis & Eigenvalue & Trace Statistics Value & Crtiticial Value (0.05) & p- Probability Value \\
\hline None & 0.493920 & 19.33919 & 20.26184 & 0.0666 \\
At least One & 0.213257 & 5.036934 & 9.164546 & 0.0494 \\
\hline
\end{tabular}

Table (5): Johansen - Juselius cointegration - Maximum test

\begin{tabular}{lllll}
\hline Hypothesis & Eigenvalue & Trace Statistics Value & Crtiticial Value (0.05) & p- Probability Value \\
\hline None & 0.493920 & 14.30226 & 15.89210 & 0.0874 \\
At least One & 0.463201 & 4.247802 & 8.483121 & 0.0493 \\
\hline
\end{tabular}

When Tables 4 and 5 are examined, when the results of the Johansen-Juselius cointegration test are examined, when both the maximum eigenvalue test and the trace test results are examined, it is seen that there is a long-term cointegration relationship between the variables $(\mathrm{p}<0.05)$. In addition, cointegration coefficients with Fully Modified Least Squares (FMOLS) and Dynamic Least Squares (DOLS) techniques are analyzed in detail in Tables 6 and 7.

Table (6): Fully Modified Least Squares test

\begin{tabular}{lllll}
\hline Variable & Coefficients & Standard Error & t- Statistics Value & p- Probability Value \\
\hline Petroleum Price & -0.041282 & 0.659072 & 0.517821 & 0.0156 \\
Constant & -1.68140 & 1.290691 & 12.14961 & 0.0000 \\
\hline
\end{tabular}

Table (7): Dynamic Least Squares testi

\begin{tabular}{lllll}
\hline Variable & Coefficients & Standard Error & t- Statistics Value & p- Probability Value \\
\hline Petroleum Price & -0.073885 & 0.808568 & 0.709755 & 0.0375 \\
Constant & -1.85418 & 1.068621 & 14.83611 & 0.0000 \\
\hline
\end{tabular}

When Tables 6 and 7 are examined, it is seen that probe values are insignificant (probe $<0.05$ ) according to FMOLS and DOLS test results. In this case, according to the results of the Fully Modified Least Squares test, there is a cointegration between oil price and the exchange rate, and a one-unit increase in oil price causes a 0.04 decrease in the real exchange rate. At the same time, this relationship is a negative relationship. In addition, a negative relationship was found according to the Dynamic Least Squares test result and a one-unit increase in oil price causes a 0.07 decrease in the real exchange rate. Table 8 below gives us the Granger Causality test results. 
Table (8): Granger Causality test

\begin{tabular}{|c|c|c|c|}
\hline Hypothesis & $\begin{array}{ll}\begin{array}{l}\text { Number } \\
\text { Observations }\end{array} & \text { of } \\
\end{array}$ & F- Statistics Value & p- Probability Value \\
\hline $\begin{array}{l}\text { Petroleum Price cause Real Exchange } \\
\text { Rate }\end{array}$ & 22 & 11.7428 & 0.006 \\
\hline $\begin{array}{l}\text { Real Exchange Rate cause Petroleum } \\
\text { Price }\end{array}$ & 22 & 0.02471 & 0.9756 \\
\hline
\end{tabular}

When Table 8 is examined, when the results of Granger causality test are analyzed, it is seen that the main hypothesis stating that oil pricecause real exchange rate is rejected $(\mathrm{p}<0.05)$. In this case, it is seen that oil price cause real exchange rate. When the results obtained from the causality analysis are interpreted, the direction of causality can only be interpreted as from oil price to the real exchange rate.

\section{Conclusion}

The oil and natural gas sector has an important share in the Iraqi economy. Therefore, the real exchange rate in Iraq is expected to be sensitive to world oil prices. However, the relationship between the real exchange rate and oil prices may differ due to the wealth and portfolio channels, that is, the spending patterns of oil revenues.

In the study examining the relationship between oil prices and real exchange rate for Iraq for the period 1995-2019, the Johansen-Juselius cointegration test and Granger causality test, which are frequently used in the literature, as well as FMOLS and DOLS analyzes were used to determine long-term cointegration coefficient estimates. According to the results of the cointegration analysis, it is seen that there is a cointegration relationship between the two variables. In FMOLS and DOLS analyzes performed to determine the long-term cointegration coefficient, a negative relationship was found between oil prices and real exchange rate. In this case, the increase in oil prices causes a decrease in the real exchange rate. According to the results of the Granger causality test, which was conducted to examine the causality aspect, a one-way causality relationship was found from oil prices to the real exchange rate.

Since real exchange rate stability has an impact on competitiveness, it is especially important for the development of other sectors of the Iraqi economy, excluding oil and natural gas. The strong reflection of the changes in oil prices in the international markets to the real exchange rate affects the competitiveness of the sectors excluding oil and natural gas. The fact that the development of these sectors is among the priority economic policies of Iraq makes it important for them to maintain a competitive and at the same time stable real exchange rate.

\section{References}

[1] R. A. Amano, and S. Van Norden. Exchange rates and oil prices. Review of International Economics, 6(4) (1998): 683694.

[2] R. A. Amano, and S. Van Norden. Oil prices and the rise and fall of the US real exchange rate. Journal of international Money and finance, 17(2) (1998): 299-316. https://doi.org/10.1016/s0261-5606(98)00004-7

[3] H. ALTINTAŞ, Türkiye'de petrol fiyatları, ihracat ve reel döviz kuru ilişkisi: ARDL sınır testi yaklaşımı ve dinamik nedensellik analizi. Uluslararası Yönetim İktisat ve İşletme Dergisi, 9(19) (2013): 1-30. https://doi.org/10.11122/ijmeb.2013.19.459

[4] Y. ALTUN and Ş. İŞLEYEN. Türkiye'de İktisadi Büyüme ile Sanayi Sektöründe İstihdam Arasındaki İlișkinin ARDL Sınır Testi Yaklaşımı ile Ekonometrik Analizi: 1991-2017. Igdir University Journal of Social Sciences, 17 (2019).

[5] Y. ALTUN, Ş. İŞLEYEN, and Ç. GÖRÜR. TÜRKIYE'DE EĞiTIM VE SAĞLIK HARCAMALARININ EKONOMIK BÜYÜMEYE ETKİII: 1999-2017. Yüzüncü Yıl Üniversitesi Sosyal Bilimler Enstitüsü Dergisi, 39 (2018): 223-244.

[6] J. Beckmann, R. Czudaj, and V. Arora. The relationship between oil prices and exchange rates: theory and evidence. US Energy Information Administration working paper series, (2017): 1-62.

[7] V. Bodart, B. Candelon, and J. F. Carpantier. Real exchanges rates, commodity prices and structural factors in developing countries. Journal of International Money and Finance, 51 (2015): 264-284. https://doi.org/10.1016/j.jimonfin.2014.11.021

[8] K. Chaudhuri and B. C. Daniel. Long-run equilibrium real exchange rates and oil prices. Economics letters, 58(2) (1998): 231-238. https://doi.org/10.1016/s0165-1765(97)00282-6

[9] Y. Demir. OECD ülkelerine ait çeşitli enerji tüketimleri ve ekonomik büyüme arasındaki ilișkinin panel eşbütünleșme analizi ile incelenmesi. Ekoist: Journal of Econometrics and Statistics, 32 (2020): 15-33.

[10] D. A. Dickey and W. A. Fuller. Likelihood ratio statistics for autoregressive time series with a unit root. Econometrica: journal of the Econometric Society, 49(4) (1981): 1057-1072. https://doi.org/10.2307/1912517

[11] D. A. Dickey and W. A. Fuller. Distribution of the estimators for autoregressive time series with a unit root. Journal of the American statistical association, 74(366a) (1979): 427-431. https://doi.org/10.2307/2286348

[12] W. Enders and P. L. Siklos. Cointegration and threshold adjustment. Journal of Business \& Economic Statistics, 19(2) (2001): 166-176. 
[13] R. F. Engle and C. W. Granger. Co-integration and error correction: representation, estimation, and testing. Econometrica: journal of the Econometric Society, 55 (2) (1987): 251-276. https://doi.org/10.2307/1913236

[14] S. Güneș, S. P. Gürel, B. Cambazoğlu. Dıș ticaret hadleri, dünya petrol fiyatları ve döviz kuru ilişskisi, yapısal var analizi: Türkiye örneği. (2013).

[15] Ş. İşleyen, Y. Altun, and Ç. Görür. The Causality Relationship Between Interest Rate and Income with Investment in USA: 1965-2016. The Journal of Academic Social Science, 5(60) (2017): 146-163.

[16] S. Johansen. Statistical analysis of cointegration vectors. Journal of economic dynamics and control, 12(2-3) (1988): 231-254. https://doi.org/10.1016/0165-1889(88)90041-3

[17] S. Johansen and K. Juselius. Maximum likelihood estimation and inference on cointegration- with applications to the demand for money. Oxford Bulletin of Economics and statistics, 52(2) (1990): 169-210. https://doi.org/10.1111/j.14680084.1990.mp52002003.x

[18] I. Korhonen and S. Ledyaeva. Trade linkages and macroeconomic effects of the price of oil. Energy Economics, 32(4) (2010): 848-856. https://doi.org/10.1016/j.eneco.2009.11.005

[19] P. R. Krugman. Oil and the dollar. NBER working paper w0554 (1980).

[20] P. Krugman, 8. Oil Shocks and Exchange Rate Dynamics. University of Chicago Press, (2010).

[21] A. L. Ngoma, N. W. Ismail, and Z. Yusop. An analysis of real oil prices and real exchange rates in five African countries: Applying symmetric and asymmetric cointegration models. Foreign Trade Review, 51(2) (2016): 162-179. https://doi.org/10.1177/0015732515625718

[22] M. Sevüktekin and M. Nargeleçekenler. Ekonometrik Zaman Serileri Analizi, Geliştirilmiş 3. Baskı, Nobel Yayın Dağıtım, Ankara (2010).

[23] Z. Taha and B. Shilan, Impacts of Oil Price on Exchange rate: Evidence from Iraq. Black Sea Journal of Management and Marketing 2(3) (2021): 1-11.

[24] S. Y. TETIK and Y. T. D. AKDİ. Türkiye'de ekonomik büyüme ile enerji harcamaları arasındaki ilişki. PhD diss., Ankara Üniversitesi Fen Bilimleri Enstitüsü İstatistik Anabilim Dalı, 2011.

[25] World Bank, https://databank.worldbank.org/source/world-development-indicators, (Date of access: 10.05.2021) 